P-ISSN: 1978-7227 E-ISSN: 2615-3017

doi : https://doi.org/10.30598/barekengvol14iss1pp039-046

National Accredited in SINTA 3, Decree No.: 28/E/KPT/2019

\title{
PENDEKATAN GEOGRAPHICALLY WEIGHTED ZERO INFLATED POISSON REGRESSION (GWZIPR) DENGAN PEMBOBOT FIXED BISQUARE KERNEL PADA KASUS DIFTERI DI INDONESIA
}

\author{
Approach of Geographically Weighted Zero Inflated Poisson Regression \\ (GWZIPR) With Weighting Function Used is Fixed Bisquare Kernel Case of \\ Diphtheria in Indonesia
}

\author{
Ismah $^{1 *}$, I Made Sumertajaya ${ }^{2}$, Anik Djuraidah ${ }^{2}$, Anwar Fitrianto $^{2}$ \\ ${ }^{1}$ Pendidikan Matematika, Fakultas Ilmu Pendidikan, Universitas Muhammadiyah Jakarta \\ Jl. KH. Ahmad Dahlan Cirendeu Ciputat, Tangerang Selatan, Banten, 15419, Indonesia \\ ${ }^{2}$ Departemen Statistika, Fakultas MIPA, Institut Pertanian Bogor \\ Jl. Raya Dramaga, Babakan, Dramaga, Babakan, Kec. Dramaga, Bogor, Jawa Barat, Indonesia \\ e-mail: $1 *$ ismah.fr@gmail.com; ${ }^{2}$ anikdjuraidah@gmail.com. \\ Corresponding author*
}

\begin{abstract}
Abstrak
Jumlah kematian orang akibat penyakit difteri merupakan data cacahan dan muncul keberadaan nol yang cukup banyak (excess zeros). Selain itu data penyebaran penyakit pada umumnya berorientasi pada geografis atau diamati di setiap wilayah tertentu, yang merupakan jenis data spasial. Geographically Weighted Zero Inflated Poisson Regression (GWZIPR), sebagai pengembangan dari model Geographically Weighted Regression (GWR) dan Zero Inflated Poisson (ZIP) akan digunakan sebagai model dalam mengolah data difteri tingkat provinsi di Indonesia tahun 2018, dengan variabel bebasnya yaitu persentase jumlah kasus difteri (X1), persentase jumlah yang divaksinasi (X2) dan persentase jumlah penduduk (X3) di setiap provinsi di Indonesia. Pendugaan parameter model menggunakan metode maximum likelihood estimation. Sedangkan fungsi pembobot yang digunakan fixed bisquare kernel. Data diolah menggunakan software $\mathrm{R}$ packages lctools. Hasil penelitian diperoleh jika pada model melibatkan ketiga variabel bebas maka pengaruh ketiga variabel bebas tersebut terhadap jumlah kematian orang akibat difteri tidak signifikan. Hal ini disebabkan terdapat hubungan yang kuat dan signifikan antar variabel bebas, sehingga apabila model tidak melibatkan variabel persentase jumlah (kepadatan) penduduk, persentase jumlah orang yang divaksinasi mempengaruhi jumlah kematian orang yang disebabkan oleh penyakit difteri secara signifikan di suatu wilayah. Sehingga pemberian vaksin imunisasi dapat mengurangi jumlah kematian yang diakibatkan oleh penyakit difteri.
\end{abstract}

Kata Kunci : Geographically weighted zero inflated poisson regression, fixed bisquare kernel.

\begin{abstract}
The number of deaths due to diphtheria is counts data and there is a considerable presence of zeros (excess zeros). Besides, data on the spread of disease are generally geographically oriented or observed in each particular region, which is a type of spatial data. Geographically Weighted Zero Inflated Poisson Regression (GWZIPR), as the development of Geographically Weighted Regression (GWR) and Zero Inflated Poisson (ZIP) models will be used as a model in processing provincial diphtheria data in Indonesia in 2018, with the independent variable percentage of diphtheria cases (X1), percentage of vaccinated numbers (X2) and percentage of the population (X3) in each province in Indonesia. Estimating model parameters uses the method of maximum likelihood estimation. While the weighting function used is fixed bisquare kernel. Data is processed using software R packages lctools. The results were obtained if the model involved all three independent variables, the effect of the three independent variables on the number of deaths due to diphtheria was not significant. This is because there is a strong and significant relationship between independent variables, so that if the model does not involve a variable percentage of the population (population density), the percentage of vaccinated people affects the number of deaths caused by diphtheria significantly in an area. So that the provision of immunization vaccines can reduce the number of deaths caused by diphtheria
\end{abstract}

Keywords: Geographically weighted zero inflated poisson regression, fixed bisquare kernel 


\section{PENDAHULUAN}

Difteri adalah salah satu penyakit yang dapat dicegah dengan pemberian vaksin imunisasi (DPT3). Difteri disebabkan oleh bakteri Corynebacterium diphtheriae yang menggangu sistem pernafasan. Berdasarkan profil kesehatan di Indonesia tahun 2017 oleh Kementerian Kesehatan RI tahun 2018 [1], penyakit difteri pada umumnya diderita oleh anak-anak usia 1-10 tahun. Jumlah kasus difteri pada tahun 2017 sebanyak 954 dengan jumlah kasus yang meninggal sebanyak 44, sehingga Case Fatality Rate (CFR) difteri di Indonesia pada 2017 yaitu sebesar 4,61\%. Kasus tertinggi terjadi di Jawa Timur sebanyak 331 kasus dan Jawa Barat yaitu 167 kasus. Sedangkan pada tahun 2018 Berdasarkan profil kesehatan di Indonesia tahun 2018 oleh Kementerian Kesehatan RI tahun 2019 [2], total kasus difteri meningkat menjadi 1.665 dengan jumlah yang meninggal sebanyak 29 orang.

Meskipun difteri adalah penyakit yang dapat dicegah melalui pemberian vaksin imunisasi, namun berdasarkan profil kesehatan Indonesia [2] diperoleh beberapa kasus difteri diderita oleh orang yang telah diberikan vaksin imunisasi. Oleh karena itu perlu kajian terhadap kasus penyakit difteri yang mengakibatkan kematian, dimana jumlah kematian pada kasus difteri merupakan data cacahan dan terdapat nilai nol yang cukup banyak.

Data cacahan adalah salah satu jenis dari varians data yang sering atau banyak ditemui. Pemodelan data cacahan dapat dilakukan menggunakan regresi poisson [3]. Regresi poisson memiliki asumsi diantaranya varians dari variabel respon $\left(\operatorname{var}\left(\mathrm{Y}_{i}\right)\right)$ sama dengan ekspektasi dari variabel respon $\left(E\left(Y_{i}\right)\right)$ [4]. Namun pada kenyataannya sering ditemukan data dengan nilai varians dari variabel respon lebih besar dari ekspektasi variabel respon, dengan demikian kasus seperti ini dinamakan overdispersi. Salah satu akibat terjadinya overdispersi adalah banyaknya keberadaan nilai nol pada data (excess zeros). Sehingga dibutuhkan pemodelan yang lebih tepat dalam mengatasi permasalahan overdispersi dengan excess zeros. Zero Inflated Poisson Regression (ZIPR) merupakan salah satu metode yang dapat digunakan ketika terdapat kasus overdispersi pada data. Selain ZIPR terdapat metode lainnya yang dapat digunakan dalam memodelkan data cacahan dengan varians variabel respon besar yang diakibatkan oleh excess zeros, yaitu model zero inflated negative binomial (ZINB), zero inflated generalized Poisson (ZIGP), zero inflated double Poisson (ZIDP), zero inflated inverse trinomial (ZIIT) dan zero inflated strict arcsine (ZISA) [5]. Namun ZIPR dan ZINB lebih populer digunakan oleh banyak peneliti, dikarenakan banyak hasil penelitian terkait dengan ZIPR dan ZINB yang telah dilakukan.

Data pada kasus jumlah orang yang meninggal akibat menderita penyakit difteri berorientasi pada geografis. Data yang berorientasi pada geografis atau yang memiliki gambaran suatu wilayah disebut dengan data spasial. Data spasial sangat umum digunakan dalam menangani permasalahan bencana, kemiskinan, sebaran penyakit (epidemik), kematian bayi yang dilahirkan, akses air bersih, dan lain sebagainya. Penyebaran penyakit pada umumnya diamati di setiap wilayah seperti di negara Indonesia berdasarkan kepulauan, atau tingkat provinsi, kabupaten kota, kecamatan, atau bahkan tingkat kelurahan. Namun untuk kasus penyebaran penyakit atau tingkat kematian yang dikarenakan penyakit tertentu sering diperoleh data dengan excess zeros, sehingga penggunaan ZIPR kurang tepat digunakan karena tidak melibatkan efek spasial. Metode yang digunakan untuk mengevaluasi hubungan antara satu atau lebih variabel dengan melibatkan efek spasial pada beberapa wilayah atau lokasi yang menjadi pusat pengamatan adalah regresi spasial [6]. Pengembangan metode untuk menganalisis data spasial yaitu Geographically Weighted Regression (GWR) yang dikembangkan oleh Fotheringham dkk [7]. GWR merupakan teknik pemodelan yang dirancang untuk menangani spasial non-stasioneritas, seperti nilai rata-rata bervariasi berdasarkan lokasi. Hal ini telah banyak digunakan sebagai alat visualisasi untuk mengeksplorasi pola data spasial [8].

Tujuan dari penelitian ini yaitu menerapkan geographically weighted zero inflated poisson regression (GWZIPR) dengan pembobot fixed bisquare kernel untuk membentuk pemodelan penyakit difteri di Indonesia. Sedangkan manfaat dari penelitian ini akan diperoleh suatu model yang efektif dan mengetahui faktor-faktor yang mempengaruhi terjadinya kematian seseorang karena terjangkit penyakit difteri di Indonesia.

Pemodelan data spasial dengan peubah respon berupa data cacahan dan kondisi data excess zeros, dapat menggunakan model Geographically Weighted Zero Inflated Poisson Regression (GWZIPR), sebagai pengembangan dari model GWR dan ZIP yang dikenalkan oleh Kalogirou [9]. Parameter model GWZIPR diduga menggunakan matriks pembobot, dimana pemberian bobot pada data disesuaikan dengan kedekatan antar wilayah pengamatan ke-i dengan wilayah pengamatan ke-j [10]. Model GWZIPR diharapkan tepat 
digunakan pada data jumlah kematian orang yang diakibatkan oleh penyakit difteri tingkat provinsi di Indonesia tahun 2018.

Zero Inflated Poisson Regression (ZIPR) dikenalkan oleh Lambert untuk mengatasi data cacahan yang memiliki excess zeros [11]. Fungsi peluang $y_{\mathrm{i}}$ sebagai berikut [12]:

$$
\begin{gathered}
P\left(Y_{i}=y_{i}\right)=\left\{\begin{array}{c}
\omega_{i}+\left(1-\omega_{i}\right) e^{-\mu_{i}}, y_{i}=0 \\
\left(1-\omega_{i}\right) \frac{e^{-\mu_{i}} \mu_{i} y_{i}}{y_{i} !}, y_{i}=1,2, \ldots, ; 0 \leq \omega_{i} \leq 1
\end{array}\right. \\
\text { dengan } \mu_{i}=\exp \left(x_{i}^{T} \beta\right) \text { dan } \omega_{i}=\frac{\exp \left(x_{i}^{T} \gamma\right)}{1+\exp \left(x_{i}^{T} \gamma\right)}
\end{gathered}
$$

Sedangkan model ZIPR seperti berikut ini

$$
\begin{gathered}
\ln \mu_{i}=\beta_{0}+\beta_{1} x_{i 1}+\cdots+\beta_{k} x_{i k} ; i=1,2, \ldots, n \\
\operatorname{logit} \omega_{i}=\gamma_{0}+\gamma_{1} x_{i 1}+\cdots+\gamma_{k} x_{i k} ; i=1,2, \ldots, n
\end{gathered}
$$

Dimana $\beta_{(k+1) \times 1}$ dan $\gamma_{(k+1) \times 1}$ adalah vektor parameter model ZIPR. Pendugaan parameter diperoleh menggunakan metode maximum likelihood estimation (MLE) dengan algoritma expectation maximization (EM). Algoritma EM adalah metode iteratif untuk memaksimalkan fungsi likelihood. Adapun bentuk persamaan fungsi likelihood seperti berikut ini,

$$
\begin{aligned}
\ln L(\beta, \gamma \mid y, z)= & \sum_{i=1}^{n}\left(z_{i} x_{i}^{T} \gamma-\ln \left(1+\exp \left(x_{i}^{T} \gamma\right)\right)\right)-\sum_{i=1}^{n}\left(1-z_{i}\right) \ln \left(y_{i} !\right) \\
& +\sum_{i=1}^{n}\left(1-z_{i}\right)\left(y_{i} x_{i}^{T} \beta-\exp \left(x_{i}^{T} \beta\right)\right)
\end{aligned}
$$

Efek spasial pada data mengharuskan diperoleh matriks pembobot spasial. Pemberian bobot dilakukan untuk memberikan tindakan yang berbeda dalam memperoleh penduga parameter pada setiap pengamatan yang berbeda. Pembobot menurut Chasco dkk diperoleh berdasarkan jarak antara wilayah $\left(u_{i}, v_{i}\right)$ dengan wilayah $\left(u_{j}, v_{j}\right)$ menggunakan jarak Euclidean sebagai berikut [13].

$d_{i j}=\sqrt{\left(u_{i}-u_{j}\right)^{2}+\left(v_{i}-v_{j}\right)^{2}}$ dan

fixed bisquare kernel $w_{i j}=\left\{\begin{array}{c}\left(1-\left(\frac{d_{i j}}{h}\right)^{2}\right)^{2}, \text { jika } d_{i j} \leq h \\ 0, \text { lainnya }\end{array}\right.$

Geographically Weighted Zero Inflated Poisson Regression (GWZIPR), adalah model pengembangan dari Geographically Weighted Regression (GWR) dan ZIP yang dikenalkan oleh Kalogirou. GWZIPR melibatkan efek spasial dalam menyelesaikan data cacahan dan memiliki nilai nol yang banyak (excess zeros). Dikarenakan GWZIPR merupakan pengembangan dari model ZIP maka fungsi peluang seperti pada persamaan (1) dimana $\mu_{i}=\exp \left(x_{i}^{T} \beta\left(u_{i}, v_{i}\right)\right)$ dan $\omega_{i}=\frac{\exp \left(x_{i}^{T} \gamma\left(u_{i}, v_{i}\right)\right)}{1+\exp \left(x_{i}^{T} \gamma\left(u_{i}, v_{i}\right)\right)}$, dengan melibatkan efek spasial pada masing-masing pengamatan dari wilayah yang berbeda-beda $\left(u_{i}, v_{i}\right) . \beta\left(u_{i}, v_{i}\right)$ dan $\gamma\left(u_{i}, v_{i}\right)$ adalah parameter regresi pada wilayah $\left(u_{i}, v_{i}\right)$.

Penduga parameter model GWZIPR menggunakan metode MLE dan algoritma EM, fungsi likelihood dan log-natural likelihood model GWZIPR ditunjukkan pada persamaan berikut ini: 


$$
\begin{aligned}
\mathrm{L}\left(\beta\left(\mathrm{u}_{\mathrm{i}}, \mathrm{v}_{\mathrm{i}}\right), \gamma\left(\mathrm{u}_{\mathrm{i}}, \mathrm{v}_{\mathrm{i}}\right)\right) & \\
= & \prod_{\mathrm{i}=1}^{\mathrm{n}} \frac{\exp \left(\mathrm{x}_{\mathrm{i}}^{\mathrm{T}} \gamma\right)+\left(\exp \left(-\exp \left(\mathrm{x}_{\mathrm{i}}^{\mathrm{T}} \beta\right)\right)\right)}{1+\exp \left(\mathrm{x}_{\mathrm{i}}^{\mathrm{T}} \gamma\right)} \\
+ & \frac{\prod_{\mathrm{i}=1}^{\mathrm{n}} \frac{1}{1+\exp \left(\mathrm{x}_{\mathrm{i}}^{\mathrm{T}} \gamma\right)}\left(\exp \left(-\exp \left(\mathrm{x}_{\mathrm{i}}^{\mathrm{T}} \beta\right)\right)\right)\left(-\exp \left(\mathrm{x}_{\mathrm{i}}^{\mathrm{T}} \beta\right)\right)^{\mathrm{y}_{\mathrm{i}}}}{\prod_{\mathrm{i}=1}^{\mathrm{n}} \mathrm{y}_{\mathrm{i}} !} \\
\ln \mathrm{L}\left(\beta\left(\mathrm{u}_{\mathrm{i}}, \mathrm{v}_{\mathrm{i}}\right), \gamma\left(\mathrm{u}_{\mathrm{i}}, \mathrm{v}_{\mathrm{i}}\right)\right) & \\
= & \sum_{\mathrm{i}=1}^{\mathrm{n}} \ln \left(\exp \left(\mathrm{x}_{\mathrm{i}}^{\mathrm{T}} \gamma\right)+\left(\exp \left(-\exp \left(\mathrm{x}_{\mathrm{i}}^{\mathrm{T}} \beta\right)\right)\right)\right) \mathrm{w}_{\mathrm{i} 1}\left(\mathrm{u}_{\mathrm{i}}, \mathrm{v}_{\mathrm{i}}\right) \\
& -\sum_{\mathrm{i}=1}^{\mathrm{n}} \ln \left(1+\exp \left(\mathrm{x}_{\mathrm{i}}^{\mathrm{T}} \gamma\right)\right) \mathrm{w}_{\mathrm{i} 1}\left(\mathrm{u}_{\mathrm{i}}, \mathrm{v}_{\mathrm{i}}\right) \\
& +\sum_{\mathrm{i}=1}^{\mathrm{n}}\left(\mathrm{y}_{\mathrm{i}} \mathrm{x}_{\mathrm{i}}^{\mathrm{T}} \beta-\exp \left(\mathrm{x}_{\mathrm{i}}^{\mathrm{T}} \beta\right)\right) \mathrm{w}_{\mathrm{i} 1}\left(\mathrm{u}_{\mathrm{i}}, \mathrm{v}_{\mathrm{i}}\right)-\sum_{\mathrm{i}=1}^{\mathrm{n}} \ln \left(\mathrm{y}_{\mathrm{i}} !\right) \mathrm{w}_{\mathrm{i} 1}\left(\mathrm{u}_{\mathrm{i}}, \mathrm{v}_{\mathrm{i}}\right)
\end{aligned}
$$

dimana $\mathrm{w}_{\mathrm{i} 1}\left(\mathrm{u}_{\mathrm{i}}, \mathrm{v}_{\mathrm{i}}\right)$ adalah bobot untuk wilayah ke-i, $i=1,2, \ldots \ldots$

GWZIPR dapat dianalisis untuk seluruh wilayah atau dapat juga dianalisis per wilayah. Dalam penelitian model yang dianalisis untuk seluruh wilayah sekaligus. Penelitian terkait dengan GWZIPR telah dilakukan sebelumnya oleh Kalogirou [9] dengan hasil penelitian bahwa metode GWZIPR terbukti secara empiris lebih baik dalam menjelaskan tujuan para migran internal di Athena dibandingkan dengan ZIP. Penelitian lainnya dilakukan oleh Purhadi dkk [12] yang menunjukkan hasil berdasarkan uji F,GWZIPR dan ZIPR tidak berbeda secara signifikan. Adeliana [10] pada skripsinya mengestimasi parameter GWZIPR menggunakan data penderita penyakit tetanus neonatorum di seluruh kabupaten/kota di Provinsi Jawa Timur yang dipengaruhi oleh empat faktor secara signifikan yaitu cakupan imunisasi TT2+ terhadap jumlah ibu hamil, ibu bersalin ditolong tenaga kesehatan, cakupan kunjungan neonatal lengkap terhadap jumlah bayi, dan penangan komplikasi neonatal terhadap jumlah ibu hamil. Selain itu Amaliana [14] membandingkan dua fungsi pembobot fixed bisquare kernel dengan fixed Gaussian kernel pada model GWZIPR pada data filariasis, hasil yang diperoleh model GWZIPR dengan fixed Gaussian kernel lebih baik daripada dengan fixed bisquare kernel. Meski demikian perbedaan nilai AIC yang diperoleh dari kedua pembobot tidak berbeda secara signifikan seperti hasil penelitian Hasriani, dkk [13], sehingga dalam penelitian ini tetap menggunakan fixed bisquare kernel sebagai pembobot dalam pendekatan GWZIPR pada kasus difteri di Indoenesia.

\section{METODE PENELITIAN}

Dalam penelitian ini digunakan data jumlah kematian orang akibat menderita penyakit difteri di Indonesia berdasarkan tingkat provinsi tahun 2018, sebanyak 32 provinsi. Provinsi yang tidak terdapat kasus difteri dieliminasi seperti Bengkulu dan Nusa Tenggara Timur. Data yang digunakan adalah data sekunder yang bersumber dari Profil Kesehatan di Indonesia Tahun 2018 Kementerian Kesehatan Republik Indonesia tahun 2019 [2]. Variabel respon (Y) dalam penelitian ini adalah jumlah kematian orang yang menderita penyakit difteri tahun 2018 di Indonesia tingkat provinsi, sedangkan variabel bebas (X) yaitu persentase jumlah kasus difteri (X1), persentase jumlah yang divaksinasi (X2) dan persentase jumlah penduduk (X3). Langkah-langkah dalam menentukan parameter model GWZIPR sebagai berikut [10]:

1. Membentuk fungsi kepekatan peluang pada $y_{\mathrm{i}}$

$$
P\left(Y_{i}=y_{i}\right)=\left\{\begin{array}{c}
\omega_{i}+\left(1-\omega_{i}\right) e^{-\mu_{i}}, y_{i}=0 \\
\left(1-\omega_{i}\right) \frac{e^{-\mu_{i}} \mu_{i}^{y_{i}}}{y_{i} !}, \quad y_{i}=1,2, \ldots, ; 0 \leq \omega_{i} \leq 1
\end{array}\right.
$$


2. Membentuk fungsi likelihood

$$
\begin{gathered}
L\left(\beta, \gamma \mid y_{i}\right)=\left\{\begin{array}{c}
\prod_{i=1}^{n} \frac{\exp \left(x_{i}^{T} \gamma\right)+\left(\exp \left(-\exp \left(x_{i}^{T} \beta\right)\right)\right)}{1+\exp \left(x_{i}^{T} \gamma\right)}, y_{i}=0 \\
\frac{\prod_{i=1}^{n} \frac{1}{1+\exp \left(x_{i}^{T} \gamma\right)}\left(\exp \left(-\exp \left(x_{i}^{T} \beta\right)\right)\right)\left(-\exp \left(x_{i}^{T} \beta\right)\right)^{y_{i}}}{\prod_{i=1}^{n} y_{i} !}, y_{i}>0
\end{array}\right. \\
\beta=\beta\left(u_{i}, v_{i}\right) \text { dan } \gamma=\gamma\left(u_{i}, v_{i}\right)
\end{gathered}
$$

3. Menghitung jarak Euclidean antar titik lokasi pengamatan berdasarkan posisi geografis (garis bujur dan lintang).

4. Menghitung matriks pembobot dengan memasukkan jarak euclidean

5. Membentuk fungsi log-natural likelihood untuk $y_{\mathrm{i}}=0$ dan $y_{\mathrm{i}}>0$

a. untuk $y_{\mathrm{i}}=0$,

$$
\ln L\left(\beta, \gamma \mid y_{i}\right)=\sum_{i=1}^{n} \ln \left(\exp \left(x_{i}^{T} \gamma\right)+\left(\exp \left(-\exp \left(x_{i}^{T} \beta\right)\right)\right)\right)-\sum_{i=1}^{n} \ln \left(1+\exp \left(x_{i}^{T} \gamma\right)\right)
$$

b. untuk $y_{\mathrm{i}}>0$,

$$
\ln L\left(\beta, \gamma \mid y_{i}\right)=\sum_{i=1}^{n}\left(y_{i} x_{i}^{T} \beta-\exp \left(x_{i}^{T} \beta\right)\right)-\sum_{i=1}^{n} \ln \left(1+\exp \left(x_{i}^{T} \gamma\right)\right)-\sum_{i=1}^{n} \ln \left(y_{i} !\right)
$$

6. Pengujian kesesuaian model terhadap parameter GWZIPR berdasarkan nilai $\mathrm{z}$ atau $\operatorname{pr}(>|\mathrm{z}|)$, apabila $\operatorname{pr}(>|\mathrm{z}|)>0.05$ maka $\mathrm{H}_{0}$ ditolak. Dengan rumusan hipotesis sebagai berikut:

$$
\begin{aligned}
& \mathrm{H}_{0}: \beta_{k}=0 \\
& \mathrm{H}_{1}: \beta_{k} \neq 0 ; k=1,2,3
\end{aligned}
$$

\section{HASIL DAN PEMBAHASAN}

Kasus terjangkitnya penyakit difteri meningkat dari tahun 2017 hingga tahun 2018, berdasarkan Profil Kesehatan Di Indonesia Tahun 2017 dan 2018 yang dilakukan oleh Kementerian Keshatan Republik Indonesia. Hal ini sungguh ironis mengingat bahwa difteri adalah salah satu penyakit yang dapat diatasi melalui pemberian vaksin imunisasi (DPT3) [1], [2]. Selain itu telah tercatat terdapat jumlah kematian yang dikibatkan oleh penyakit difteri. Diseluruh provinsi di Indonesia hanya Bengkulu dan Nusa Tenggara Timur yang tidak tercatat memiliki kasus difteri tahun 2018, oleh karena itu dalam analisis data penelitian ini kedua provinsi tersebut tidak dilibatkan. Hasil olah data faktor yang menyebabkan tingkat atau jumlah kematian orang yang terjangkit difteri menaik atau menurun menggunakan software $\mathrm{R}$ dengan package lctools. Faktorfaktor yang akan dianalisis yaitu persentase jumlah kasus penderita difteri (X1), persentase jumlah yang telah divaksinasi dari jumlah penderita difteri (X2) dan persentase jumlah penduduk di masing-masing provinsi di Indonesia (X3).

Berikut hasil analisis jumlah pengamatan adalah 32 provinsi, dan fungsi pembobot yang digunakan adalah fixed bisquare kernel, serta jumlah variabel yang diamati adalah 3. Dari 32 pengamatan di ketahui bahwa excess zeros sebanyak 22 pengamatan $(68,75 \%)$. Pengujian paramater model data cacahan GWZIPR dengan distribusi poisson ditunjukkan pada tabel 1, sedangkan pengujian paramater model zero inflated GWZIPR dengan distribusi binomial ditunjukkan pada tabel 2 seperti berikut ini.

Tabel 1. Penguji Parameter Model data cacahan GWZIPR

\begin{tabular}{|c|c|c|c|c|}
\hline Variabel & Koefisien & Standard error & Z value & $\operatorname{Pr}(>|\mathbf{z}|)$ \\
\hline Intercept & 0.3435 & 0.3831 & 0.897 & 0.370 \\
X1 & 1.5570 & 3.0590 & 0.509 & 0.611 \\
X2 & 1.5269 & 3.2943 & 0.464 & 0.643 \\
X3 & 4.8580 & 4.0066 & 1.212 & 0.225 \\
\hline
\end{tabular}


Tabel 2. Penguji Parameter Model data cacahan GWZIPR

\begin{tabular}{|c|c|c|c|c|}
\hline Variabel & Koefisien & Standard error & Z value & $\operatorname{Pr}(>|\mathbf{z}|)$ \\
\hline Intercept & 4.548 & 1.865 & 2.439 & 0.0147 \\
X1 & 28.636 & 26.703 & 1.072 & 0.2836 \\
X2 & -109.930 & 57.232 & -1.921 & 0.0548 \\
X3 & -85.593 & 53.474 & -1.601 & 0.1095 \\
\hline Number of iterations in BFGS optimization: 392 & \\
Log-likelihood: -25.67 on 8 Df & & \\
Residual Sum of Squares: 38.93194 & & \\
R-squared: 0.6134589 & & \\
Adjusted -squared: 0.5561936 &
\end{tabular}

Berdasarkan Tabel 1 dan 2.diperoleh model GWZIPR sebagai berikut:

$\ln (\hat{\mu})=0.3435+1.5570 x_{1}+1.5269 x_{2}+4.8580 x_{3}$

$\hat{\mu}=\exp \left(0.3435+1.5570 x_{1}+1.5269 x_{2}+4.8580 x_{3}\right)$

$\operatorname{logit}(\widehat{\omega})=4.548+28.636 x_{1}-109.930 x_{2}-85.593 x_{3}$

Hasil analisis diketahui bahwa semua variabel (X1, X2, X3) tidak signifikan mempengaruhi jumlah kematian orang yang terjangkit difteri dengan $\alpha=5 \%$. Hal ini dapat dilihat berdasarkan nilai $\operatorname{Pr}(>|z|)$ yang diperoleh dari tabel 1 kurang dari $\alpha=5 \%$.

Berdasarkan hasil penelitian Nailul Izza dan Soenarnatalina [15] tentang analisis data spasial penyakit difteri diketahui bahwa kepadatan (jumlah) penduduk tidak berpengaruh secara signifikan terhadap timbulnya penyakit difteri. Oleh sebab itu dalam penelitian ini, dilakukan analisis dengan mengeliminasi variabel persentasi jumlah penduduk (X3) dari model. Selain itu pertimbangan lainnya adalah terjadi korelasi yang cukup kuat dan signifikan antara variabel X3 dengan X1 dan X2. Seperti yang tampak pada tabel 3 berikut ini hasil perhitungan menggunakan software SPSS.

Tabel 3. Korelasi Antar Variabel

\begin{tabular}{|c|c|c|c|c|}
\hline \multirow{2}{*}{ Variabel } & \multirow{2}{*}{ Kriteria } & \multicolumn{3}{|c|}{ Variabel } \\
\cline { 3 - 5 } & & $\mathbf{X 1}$ & $\mathbf{X 2}$ & $\mathbf{X 3}$ \\
\hline \multirow{3}{*}{ X1 } & Pearson Correlation & 1 & 0.151 & $0.505^{* *}$ \\
& Sig. (2-tailed) & & 0.411 & 0.003 \\
& $\mathrm{~N}$ & 32 & 32 & 32 \\
\hline \multirow{3}{*}{ X2 } & Pearson Correlation & 0.151 & 1 & $0.568^{* *}$ \\
& Sig. (2-tailed) & 0.411 & & 0.001 \\
& N & 32 & 32 & 32 \\
\hline \multirow{3}{*}{ X3 } & Pearson Correlation & $0.505^{* *}$ & $0.568^{* *}$ & 1 \\
& Sig. (2-tailed) & 0.003 & 0.001 & \\
& N & 32 & 32 & 32 \\
\hline
\end{tabular}

Hasil analisis model dengan melibatkan dua variabel bebas X1 dan X2 diperoleh hasil sebagai berikut:

Tabel 4. Penguji Parameter Model data cacahan GWZIPR 2 Variabel (X1 dan X2)

\begin{tabular}{|c|c|c|c|c|}
\hline Variabel & Koefisien & Standard error & $\boldsymbol{Z}$ value & $\operatorname{Pr}(>|\mathbf{z}|)$ \\
\hline Intercept & 0.3932 & 0.3914 & 1.005 & 0.3151 \\
X1 & 4.0876 & 2.3301 & 1.754 & 0.0794 \\
X2 & 3.5878 & 3.0114 & 1.191 & 0.2335 \\
\hline
\end{tabular}

Tabel 5. Penguji Parameter Model data cacahan GWZIPR 2 Variabel (X1 dan X2)

\begin{tabular}{|c|c|c|c|c|}
\hline Variabel & Koefisien & Standard error & Z value & $\operatorname{Pr}(>|\mathbf{z}|)$ \\
\hline italic & 3.320 & 1.260 & 2.634 & $0.00843^{* *}$ \\
X1 & -5.880 & 9.433 & -0.623 & 0.53302 \\
X2 & -118.877 & 52.616 & -2.259 & $0.02386^{*}$ \\
\hline
\end{tabular}






Berdasarkan tabel 4 dan 5 diperoleh model GWZIPRdengan 2 variabel (X1 dan X2) sebagai berikut:

$$
\begin{aligned}
& \ln (\hat{\mu})=0.3932+4.0876 x_{1}+3.5878 x_{2} \\
& \hat{\mu}=\exp \left(0.3932+4.0876 x_{1}+3.5878 x_{2}\right) \\
& \text { logit }(\widehat{\omega})=3.320-5.880 x_{1}-118.877 x_{2}
\end{aligned}
$$

Dan diketahui bahwa pada model logit persentase jumlah orang yang telah divaksinasi (X2) mempengaruhi jumlah kematian yang dikarenakan mengidap penyakit difteri. Hal ini dapat dilihat dari nilai $\operatorname{Pr}(>|\mathrm{z}|)<5 \%(\alpha)$ untuk variabel X2. Model GWZIPR yang terbentuk menginterpretasikan bahwa jika persentase jumlah orang yang telah divaksinasi meningkat $1 \%$ maka akan menurunkan log rata-rata jumlah kematian orang yang mengidap penyakit difteri, hal ini sesuai dengan hasil penelitian Mardiana [16] pemberian imunisasi berpengaruh secara signifikan. Oleh karena itu, pemberian vaksin imunisasi (DPT3) penting diberikan guna mengurangi tingkat kematian yang disebabkan oleh penyakit difteri. Sedangkan persentase jumlah kasus difteri tidak berpengaruh secara signifikan terhadap jumlah kematian orang yang mengidap penyakit difteri. Hal ini terjadi dikarenakan jumlah kasus difteri di setiap provinsi berhubungan positif dengan jumlah penduduk $(50 \%)$ berdasarkan korelasi pada tabel 3. Seperti di kota-kota besar yaitu Jakarta, Yogjakarta, Surabaya, dan kota besar lainnya yang memiliki jumlah penduduk lebih banyak dibanding dengan kota-kota kecil yang jumlah penduduknya lebih sedikit juga memiliki persentase difteri lebih besar, namun dengan pemberian vaksin imunitas yang baik yang dilakukan di kota-kota besar karena pendistribusian vaksin lebih terjangkau, akan memperkecil tingkat kematian yang diakibatkan oleh penyakit difteri, atau dengan kata lain persentase tingkat kesembuhan penderita difteri cukup tinggi.

\section{KESIMPULAN}

Penelitian ini menggunakan model GWZIPR untuk menganalisis data cacahan dengan excess zeros dan berorientasi pada geografis atau efek spasial, yaitu pada jumlah kematian orang yang terkena penyakit difteri. Secara teoritis diketahui bahwa penyakit difteri dapat dicegah dengan pemberian vaksin imunisasi (DPT3). Oleh karena itu salah satu variabel yang dilibatkan dalam model yaitu persentase jumlah orang yang telah divaksinasi, persentase jumlah kasus difteri dan persentase jumlah (kepadatan) penduduk. Hasil analisis model dalam penelitian ini dapat disimpulkan menjadi 2 bagian yaitu:

1. Hasil analisis model dengan melibatkan ketiga variabel diperoleh semua variabel tidak berpengaruh secara signifikan terhadap jumlah kematian orang yang terkena penyakit difteri. Dikarenakan terdapat hubungan yang kuat secara signifikan antara variabel persentase jumlah (kepadatan) penduduk dengan persentase jumlah kasus difteri dan persentase jumlah orang yang telah divaksinasi, maka variabel persentase jumlah (kepadatan) penduduk dieliminasi dari model.

2. Hasil analisis model tanpa variabel persentase jumlah (kepadatan) penduduk menunjukkan bahwa persentase jumlah orang yang telah divaksinasi berpengaruh secara signifikan terhadap jumlah kematian orang yang terkena penyakit difteri, semakin banyak orang yang diberi vaksin imunisasi (DPT3) maka jumlah kematian yang diakibatkan oleh penyakit difteri akan semakin menurun.

\section{DAFTAR PUSTAKA}

[1] Kementerian Kesehatan RI, "Profil Kesehatan di Indonesia Tahun 2017”, Jakarta: Kementerian Kesehatan Republik Indonesia. [Online]. Tersedia: https://www.depkes.go.id/resources/download/pusdatin/profilkesehatan-indonesia/Profil-Kesehatan-Indonesia-tahun-2017.pdf. [Diakses: 05 Juli 2019] 
[2] Kementerian Kesehatan RI, "Profil Kesehatan Di Indonesia Tahun 2018", Jakarta: Kementerian Kesehatan Republik Indonesia. [Online]. Tersedia: https:/www.depkes.go.id/resources/download/pusdatin/profilkesehatan-indonesia/profil-kesehatan-indonesia-2018.pdf [Diakses: 05 Juli 2019]

[3] N. Ismail and A. A. Jemain, Handling Overdispersion with Negative Binomial and Generalized Poisson Regression Models. Casualty Actuarial Society Forum, Winter 2007. [Online]. Tersedia: https://www.casact.org/pubs/forum/07wforum/07w109.pdf

[4] P. Mccullag dan J.A. Nelder, Generalized Linear Models, 2nd edition, Chapman \& Hall, London, 1989.

[5] Y. N. Phang and E. F. Loh, Zero Inflated Models for Overdispersed Count Data, International Journal of Health and Medical Engineering, Vol. 7, No. 8: 1331-1333. 2013.

[6] I. F. Fatati, H. Wijayanto, dan A. M. Sholeh, "Analisis Regresi Spasial dan Pola Penyebaran pada Kasus Demam Berdarah Dengue (DBD) di Provinsi Jawa Tengah”, Media Statistika, 10(2) 2017: 95-105. 2017. [Online]. Tersedia: https://ejournal.undip.ac.id/index.php/media_statistika/article/view/18274

[7] A. Fotheringham, C. Brunsdon, dan M. Charlton, Geographically Weighted Regression The Analysis of Spatially Varying Relationships, John Wiley \& Sons Ltd. England. 2002. [Online]. Tersedia: https://www.researchgate.net/publication/27246972_Geographically_Weighted_Regression_The_Analysis_of _Spatially_Varying_Relationships

[8] Y. Y. Leong dan J. C. Yue, A modification to geographically weighted regression, International Journal of Health Geographics, 16: 11. 2017. [Online]. Tersedia: https://ijhealthgeographics.biomedcentral.com/articles/10.1186/s12942-017-0085-9

[9] S. Kalogirou, Destination Choice of Athenians: an application of geographically weighted versions of standard and zero inflated Poisson spatial interaction models. Geographical Analysis. 48(2),pp. 191-230. DOI: 10.1111/gean.12092. 2016.

[10] Adeliana, "Estimasi Parameter Geographically Weighted Zero Inflated Poisson Regression (GWZIPR) dengan Pembobot Fixed Bisquare Kernel", Skripsi, Universitas Islam Negeri Maulana Malik Ibrahim : Malang, 2018.

[11] D. Lambert, Zero-Inflated Poisson Regression, with an Application to Defects in Manufacturing. Technometrics. [Online]. Vol. 34, No. 1 (Feb., 1992), pp. 1-14. Tersedia: http://www.jstor.org/stable/1269547

[12] Purhadi, Y. S. Dewi dan L. Amaliana, Zero Inflated Poisson and Geographically Weighted Zero Infalted Poisson Regression Model : Application to Elephantiasis (Filariasis) Count Data. Journal of Mathematics and Statistics. 11 (2): 52-6. 2015.

[13] Hasriana, Raupong, dan N. Ilyas, "Pemodelan Kemiskinan Menggunakan Geographically Weighted Logistic Regression Dengan Fungsi Pembobot Fixed Kernel", 2017. [Online]. Tersedia: https://core.ac.uk/download/pdf/77625402.pdf. [Diakses 20 Mei 2019].

[14] L. Amaliana, A. A. R. Fernandes dan Solimun, Comparison of Two Weighting Functions in Geographically Weighted Zero-Inflated Poisson Regression on Filariasis Data, IOP Conf. Series: Journal of Physics: Conf. Series 1097 (2018) 012070, Doi :10.1088/1742-6596/1097/1/012070, 2018. [Online]. Tersedia: https://iopscience.iop.org/article/10.1088/1742-6596/1097/1/012070

[15] I. Nailul dan Soenarnatalina, “Analisis Data Spasial Penyakit Difteri di Provinsi Jawa Timur Tahun 2010 Dan 2011”, Buletin Penelitian Sistem Kesehatan - Vol. 18 No. 2 April 2015: 211-219, 2015.

[16] D.E. Mardiana, "Pengaruh Imunisasi dan Kepadatan Penduduk terhadap Prevalensi Penyakit Difteri di Jawa Timur". Jurnal Berkala Epidemiologi. [Online]. Volume 6 Nomor 2 (2018) 122-129. Tersedia: http://journal.unair.ac.id/index.php/JBE/ 